\title{
Pines, 2nd revised edition
}

\section{Drawings and Descriptions of the Genus Pinus}

Author: Aljos Farjon

There has been a steady demand for the first edition of the conifer book PINES, which sold out in 2002. Therefore, a second edition, which is a modest update, was written. The book Pines was never an attempt at monograph in the taxonomic sense. Rather it was an overview with line drawings of the commonly known species of pines, giving concise but essential information on identification, distribution and ecology. Introductory texts explained botanical characteristics of pines and a chapter on classification, one on phylogeny and biogeography, and a glossary, index and short bibliography completed the book. This scope and structure have been maintained in the second edition. It was necessary to make several taxonomic changes, to add or omit a few species, present a new chapter on phylogeny and classification and amend or correct, even expand, some of the information given in the first edition, especially in the species accounts. Conservation aspects have been added to species accounts in a concise format, following IUCN evaluations. The author has maintained the original drawings and made amendments only to correct errors; drawings for additional species have been added in the same style. The book contains a total of 92 drawings and 103 distribution maps. With these amendments the information should have been updated to a satisfactory level, without altering the original...

See More

\section{Readership}

This book is an introduction to the genus Pinus that should appeal to 'dendrologists' as well as to botanists and students who take an interest in this remarkable genus.

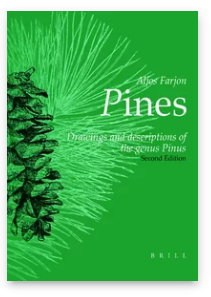

Pages: $235 \mathrm{pp}$., 9 o plates, 12 figures, frontisp.

Language:

English

Subjects:

Botany, Biology,

General, Biology

Publisher: Brill

E-Book (PDF)

Released online:

25 May 2021

ISBN: $978-90-$

47-41516-9

List price

USD $\$ 124.00$

Hardback

Publication date:

18 Apr 2005

ISBN: 978-90-

04-13916-9

Paperback

Publication date:

O7 Jun 2018

ISBN: 978-90-

04-37164-4

List price

USD $\$ 124.00$ 
For more information see brill.com

Order information: Order online at brill.com +44330 333 0049 | customerservices@brill.com Submission information: brill.com/authors

Titles published by Brill | Fink, Brill | mentis or Brill | Schöningh: +49(o)715413279216| brill@brocom.de 